\title{
IMPLEMENTASI PERTANGGUNG JAWABAN PELAKU TINDAK PIDANA KORUPSI DALAM PENYALAH GUNAAN ANGGARAN PENDAHULUAN DAN BELANJA KAMPUNG (APBK) YANG DILAKUKAN OLEH OKNUM MANTAN KEPALA KAMPUNG MENANGA JAYA (STUDI KASUS NOMOR:13/PID.SUS-TPK/2020/PN.TJK)
}

\author{
Alfarrizy $^{1}$, Bambang Hartono ${ }^{2}$ dan Zainudin Hasan ${ }^{3}$ \\ Program Studi Ilmu Hukum, Fakultas Hukum, Universitas Bandar Lampung \\ Jl. ZA Pagar Alam No 26, Labuhan Ratu, Kecamatan Labuhan Ratu, Kota \\ Bandar Lampung \\ Email : alfarizyy98@gmail.com ${ }^{1}$,bambang.hartono@ubl.ac.id ${ }^{2}$ \\ zainudinhasan@ubl.ac.id ${ }^{3}$
}

$\begin{array}{ll}\text { Submisson } & : 6 \text { Agustus } 2021 \\ \text { Accepted } & : 10 \text { september } 2021 \\ \text { Publish } & : 30 \text { September } 2021\end{array}$

Abstract

The term corruption comes from the Latin "corruption"(English) and "corruptive"(Dutch), the literal meaning of which refers to corrupt, rotten, dishonest actions related to finances. Tanjung Karang District Court NUMBER: 13/PID.SUS-TPK/2020/PN.TJK) with the defendant Wahid Maulana who committed a criminal act of corruption, misuse of the income budget and the village Dutch in the village of Wina Jaya. The research method used in this thesis research is normative juridical approach and empirical approach. Data collection is based on library research and field studies. The factors causing the corruption crime in the aquo case are the lack of exemplary leadership, the absence of the right organizational culture, the inadequacy of the correct accountability system, the weakness of the management control system, and weak supervision. The criminal liability of the perpetrator is carried out by convicting the defendant with imprisonment for 5 years and a fine of Rp.200,000,000,- provided that if the fine isn't paid by the defendant, it's replaced with imprisonment for 3 months. In addition, the defendant was also sentenced to pay compensation for state financial losses amounting to Rp.457,622,500. As a form of accountability and the arena meets the elements of error and intentional in committing a crime.

Keywords: criminal responsibility, corruption, APBK, village heads

\begin{abstract}
Abstrak
Istilah korupsi berasal dari bahasa latin "corruption" (Inggris) dan "corruptive" (Belanda), arti harfiahnya menunjuk pada perbuatan yang rusak, busuk, tidak jujur yang berkaitan dengan keuangan. Salah satu perkara tindak pidana kurupsi adalah pada pengadilan negri tanjung karang NOMOR:13/PID.SUS-TPK/2020/PN.TJK) dengan terdakwa Wahid Maulana yang melakukan tindak pidana korupsi penyalah gunaan anggaran pendapatan dan belanda kampung di kampung menanga jaya.Metode
\end{abstract}


penelitian yang digunakan dalam penelitian artikel ini ialah pendekatan yuridis normatif dan pendekatan empiris. Pengumpulan data berdasarkan studi kepustakaan dan studi lapangan. Faktor penyebab Tindak Pidana Korupsi perkara aquo adalah kurang adanya sikap keteladanan pimpinan, tidak adanya kultur organisasi yang benar, kurang memadainya sistem akuntabilitas yang benar,kelemahan sistem pengendalian manajeme,lemahnya pengawasan. Pertanggungjawaban Pidana pelaku dilakukan dengan pemidanaan terhadap terdakwa dengan Pidana Penjara selama 5 tahun dan denda sebesar Rp.200.000.000,- dengan ketentuan apabila denda tersebut tidak dibayar oleh terdakwa maka diganti dengan pidana kurungan selama 3 bulan. Selain itu terdakwa juga dipidana untuk membayar uang pengganti kerugian keuangan negara sebesar Rp.457.622.500,00. Sebagai bentuk pertanggungjawaban dan arena memenuhi unsur kesalahan dan kesengajaan dalam melakukan Tindak Pidana.

Kata Kunci: pertanggungjawaban pidana, korupsi, APBK, Kepala kampung

\section{A. Pendahuluan}

Istilah korupsi berasal dari bahasa latin "corruption", "corruption" (Inggris) dan "corruptive" (Belanda), arti harfiahnya menunjuk pada perbuatan yang rusak, busuk, tidak jujur yang berkaitan dengan keuangan. Sedangkan dalam Black's Law Dictionary, korupsi adalah perbuatan yang dilakukan dengan maksud untuk memberikan suatu keuntungan yang tidak resmi dengan hak-hak dari pihak lain secara salah menggunakan jabatanya atau karakternya untuk mendapatkan suatu keuntungan untuk dirinya sendiri atau orang lain, berlawanan dengan kewajibanya dan hak-hak dari pihak-pihak lain. ${ }^{1}$

Pelaksanaan hak, wewenang, dan kewajiban daerah otonom untuk melaksanakan dan mengurus sendiri urusan pemerintahan dan warga kampungnya sesuai dengan peraturan perundang-undangan secara nyata memberikan dampak positif, terutama dalam hal kesetaraan dan pelaksaan pembangunan di daerah atau kamupung, akan tetapi sampai pada saat ini belum bisa di katakan sejahtera terutama bagi rakyat kecil, selain itu oknum aparatur pemerintah daerah tidak adil kepada rakyat kerna banyak aparatur daerah yang korup dan menyalah gunakan tugas dan wewenang nya sebagai aparatur desa atau kampung.

1 Chaerudin, Syaiful Ahmad Dinar, Syarif Fadillah. Strategi Pencegahan dan Penegakan Hukum Tindak Pidana Korupsi. ( Bandung : PT Refika Aditama, 2008). hlm. 2. 
Tindakan korupsi aparat pemeritahan daerah salah satunya terjadi pada alokasi dana kampung berdasarkan RAPBK TA 2016 untuk pos-pos bidang penyelenggaraan pemerintah kampung, bidang pelaksanaan pembangunan kampung pembinaan kemasyarakatan, dan bidang pemberdayaan masyarakat .dana anggaran pendapatan dan belanja kampungseharusnya di laksanakan dengan sebaik mungkin untuk keperluan masyarakat kampung sesuai dengan peraturan yang telah di tetapkan tetapi hal tersebut tidak di jalankan dengan baik dan terjadi tindak pidana korupsi.penanggung jawab pengelola anggaran pendapatan dan belanja kampung adalah hal yg sangat penting karna mempengaruhi pekerjaan yang benar dan tepat guna mencapai suatu tujuan yang maksimal dengan mencegah timbulnya kerugian keuangan negara agar baik dengan cara pidana atau cara perdata, mengusahakan kembalinya secara maksimal dan cepat seluruh kerugian negara yang ditimbulkan oleh praktik korupsi. Keberadaan unsur kerugian negara merupakan pintu masuk dan salah satu kunci utama sukses tidaknya upaya perampasan dan pengembalian aset perolehan hasil korupsi.

Menurut Pasal 2 Undang-Undang Tipikor berbunyi: "Setiap orang yang secara melawan hukum melakukan perbuatan memperkaya diri sendiri atau orang lain atau suatu korporasi yang dapat merugikan keuangan negara atau perekonomian negara, dipidana dengan pidana penjara seumur hidup atau pidana penjara paling singkat 4 (empat) tahun dan paling lama 20 (dua puluh) tahun dan denda paling sedikit RP. 200.000.000, 00 (dua ratus juta rupiah) dan paling banyak Rp. 1.000.000.000,00 (satu miliar rupiah)"2

Secara umum dan sederhana korupsi dapat diartikan sebagai penyalahgunaan kekuasaan/kepercayaan untuk keuntungan pribadi. Pengertian korupsi juga mencakup perilaku pejabat-pejabat di sektor publik, baik politisi maupun pegawai negeri, yang memperkaya diri mereka secara tidak pantas dan melanggar hukum, atau orang-orang yang dekat dengan pejabat birokrasi dengan

2 Eddy Mulyadi Soepardi. Memahami kerugian negara sebagai salah satu unsur tindak pidana. (Yogyakarta: Ghalia, 2009) hlm. 3. 
menyalahgunakan kekuasaan yang dipercayakan pada mereka. Kehidupan korupsi dalam konteks pelayanan publik ini merupakan perbuatan "korupsi administrasi" dengan fokus pada kegiatan perorangan yang memegang kontrol dalam kedudukannya sebagai pejabat publik, sebagai pembuat kebijakan atau sebagai pegawai birokrasi pemerintah, atas berbagai kegiatan atau keputusan. Dengan makin meluasnya proyek swastanisasi perusahan negara dan pengalihan kegiatan yang selama ini dipandang masuk dalam lingkup tugas pemerintah ke sektor swasta, dan monopoli penuh atau setengah penuh penyediaan barang publik oleh sektor swasta (misalnya: air, listrik, telkom), maka perbuatan korupsi telah merambah juga pada sektor swasta di luar dan di dalam hubungan kerja sektor swasta dengan sektor publik, sehingga perbuatan korupsi kedua sektor ini membawa dampak negatif terhadap kepentingan publik.

Tindak pidana korupsi mengakibatkan kerugian negara dan menghambat pembangunan nasional terutama pembangunan kampung atau desa, sehingga harus di berantas karena dapat menghambat pembangunan nasional.

Setiap pelaku yang terbukti melakukan tindak pidana korupsi harus di pertanggung jawabkan perbuatannya di depan hukum, sesuai dengan Pasal 2 ayat 1 Undang-Undang Tindak Pidana Korupsi.

Salah satu perkara tindak pidana kurupsi adalah putusan pengalidan tindak pidana korupsi pada pengadilan negri tanjung karang NOMOR: 13/PID.SUSTPK/2020/PN.TJK) dengan terdakwa wahid maulana yang melakukan tindak pidana korupsi penyalah gunaan anggaran pendapatan dan belanda kampung di kampung menanga jaya, majelis hakim yang menangani perkara ini menjatuhkan pidana kepada terdakwa sebagaimana diatur dan diancam pidana dalam Pasal 2 ayat (1) Jo. Pasal 18 Undang-Undang Nomor 31 Tahun 1999 tentang Pemberantasan Tindak Pidana Korupsi yang dirubahdan ditambah dengan Undang-Undang Nomor 20 tahun 2001 Jo Pasal 55 ke-1 KUHP Jo pasal 64 ayat (1) KUHP dan pidana penjara selama 6 (enam) Tahun dan membayar denda Rp. 200.000.000,- (dua ratus juta rupiah) subsidiair 3 (tiga) bulan Kurungan dan pidana tambahan untuk membayar uang Pengganti sebesar Rp. 457.622.500,00 
(empat ratus lima puluh tujuh juta enam ratus dua puluh dua ribu lima ratus rupiah).

Berdasarkan latar belakang di atas, penulis akan melaksanakan penelitian untuk melihat yang di tuangkan dalam rangka penyusunan artikel ini dengan judul: "Implementasi Pertanggung Jawaban PelakuTindak Pidana Korupsi Dalam Penyalah Gunaan Anggaran Pendahuluan dan Belanja Kampung (APBK) Yang Dilakukan Oleh Oknum Mantan Kepala Kampung Menanga Jaya (Studi Kasus Nomor: 13/Pid.Sus-TPK/2020/PN.Tjk).

Berdasarkan uraian latar belakang diatas, permasalahan yang akan diambil dalam penulisan artikel ini adalah :

a. Apa yang menjadi faktor penyebab pelaku melakukan tindak pidana korupsi anggaran pendapatan dan belanja kampung menanga jaya dalam perkara nomor: 13/pid.sus-Tpk/2020/Tjk?

b. Bagaimana pertanggung jawaban pelaku tindana pidana korupsi anggaran pendapatan dan belanja kampung menanga jaya dalam perkara nomor: 13/Pid.Sus-TPK/2020/PN.Tjk?

c. Bagaimanakah upaya pengembalian kerugian negara akibat tindak pidana korupsi anggaran pendapatan dan belanja kampung menanga jaya dalam perkara nomor: 13/Pid.Sus-TPK/2020/PN.Tjk?

Metode penelitian yang digunakan dalam penelitian ini ialah pendekatan yuridis normatif dan pendekatan empiris. Pengumpulan data berdasarkan studi kepustakaan dan studi lapangan, sedangkan pengolahan data dilakukan metode editing, klasifikasi dan sistemasi data. Narasumber dalam penelitian ini meliputi Inspektorat, Badan Pemeriksa Keuangan dan Pembangunan, Penyidik, Jaksa, Penuntut Umum, Penasehat Hukum, dan Hakim. 


\section{B. Hasil Penelitian dan Pembahasan}

1. Faktor Penyebab Pelaku Melakukan Tindak Pidana Korupsi Anggaran Pendapatan dan Belanja Kampung Menanga Jaya Dalam Perkara Nomor: 13/Pid.Sus-Tpk/2020/Tjk.

Menurut Syed Hussein istilah "korupsi” pejabat disebut korup apabila seorang pegawai negeri menerima pemberian yang disodorkan oleh seorang swasta dengan maksud mempengaruhinya agar memberikan perhatian istimewa pada kepentingan- kepentingan si pemberi. Terkadang perbuatan menawarkan pemberian seperti itu atau hadiah lain yang menggoda juga tercakup dalam konsep itu. Pemerasan, yakni permintaan pemberian-pemberian atau hadiah seperti itu dalam pelaksanaan tugas-tugas publik, juga bisa dipandang sebagai "korupsi". Sesungguhnyalah, istilah itu terkadang juga dikenakan pada pejabatpejabat yang menggunakan dana publik yang mereka urus bagi keuntungan mereka sendiri; dengan kata lain, mereka yang bersalah melakukan penggelapan di atas harga yang harus dibayar publik. ${ }^{3}$

Selanjut nya Syed Hussein tipologi korupsi ada tujuh yaitu:

1. Korupsi transaktif yaitu korupsi yang menunjukan adanya kesepakatan timbal balik antara pihak yang memberi dan menerima demi keuntungan bersama dimana kedua pihak sama-sama aktif menjalankan tindak korupsi.

2. Korupsi ekstortif (memeras) yaitu korupsi yang menyertakan bentukbentuk korupsi tertentu dimana pihak pemberi dipaksa untuk menyuap agar tidak membahayakan diri, kepentingan, orang-orangnya atau hal-hal lain yang dihargainya.

3. Korupsi investif yaitu korupsi yang melibatkan suatu penawaran barang atau jasa tanpa adanya pertalian langsung dengan keuntungan tertentu yang diperoleh pemberi, selain keuntungan yang diharapkan akan diperoleh di masa datang.

3 BPKP, Strategi Pemberantasan Korupsi Nasional, (Jakarta: Pusat Pendidikan dan Pengawasan BPKP, Cet I, 1999) hlm 257-258 
4. Korupsi nepotistik (perkerabatan) yaitu korupsi berupa pemberian perlakuan khusus pada teman atau yang mempunyai kedekatan hubungan dalam rangka menduduki jabatan publik. Dengan kata lainmengutamakan kedekatan hubungan dan bertentangan dengan norma dan aturan yang berlaku.

5. Korupsi autigenik yaitu korupsi yang dilakukan individu karena mempunyai kesempatan untuk memperoleh keuntungan dari pengetahuan dan pemahamannya atas sesuatu yang hanya diketahui sendiri.

6. Korupsi suportif (Dukungan) yaitu korupsi yang memicu penciptaan suasana yang kondusif untuk melindungi atau mempertahankan keberadaan tindak korupsi.

7. Korupsi defensif yaitu tindak korupsi yang terpaksa dilakukan dalam rangka mempertahankan diri dari pemerasan."4

Andi Hamzah membuat hipotesis mengenai sebab-sebab korupsi sebagai berikut: $^{5}$

1. Kurangnya gaji atau pendapat pegawai negeri dibandingkan dengan yang makin hari makin meningkat;

Pada umumnya orang menghubung-hubungkan tumbuh suburnya korupsi sebab yang paling gambang dihubungkan misalnya kurangnya gaji pejabat-pejabat, buruknya ekonomi, mental pejabat yang kurang baik, administrasi dan manajemen yang kacau yang menghasilkan adanya prodesur yang berliku-liku dan sebagainya.

2. Tetapi banyak faktor yang bekerja dan saling mempengaruhi satu sama lain sampai menghasilkan keadaan yang kita hadapi. Yang dapat dilakukan hanyalah mengemukakan faktor-faktor yang paling berpengaruh. Buruknya ekonomi belum tentu dengan sendirinya menghasilkan suatu wabah korupsi dikalangan pejabat kalau tidak ada faktor-faktor lain yang bekerja. Kurangnya gaji bukanlah faktor yang menentukan.

Ibid hlm. 258.

Andi Hamzah.. Pemberantasan Korupsi melalui Hukum Pidana Nasional dan Internasional, (Jakarta, Raja Grafindo Persada, 2005) Hlm. 13-23 
3. Latar belakang kebudayaan atau kultur Indonesia;

Dalam hubungan meluasnya korupsi di Indonesia, apabila hal itu ditinjau lebih lanjut yang perlu diselidiki tentunya bukan kekhususan hal itu orang satu per satu, melainkan yang secara umum meliputi, dirasakan dan mempengaruhi kita semua orang Indonesia.

4. Manajemen yang kurang baik dan control yang kurang efektif dan efisien;

5. Modernisasi. $^{6}$

Faktor penyebab Tindak Pidana Korupsi dana Anggaran Pendapatan dan Belanja Kampung Menanga Jaya dalam Perkara Nomor: 13/Pid.SusTPK/2020/PN.Tjk. Faktor internal merupakan faktor penyebab korupsi yang datang dari diri pribadi. Faktor ini terdiri dua aspek perilaku, yaitu individu dan sosial. Aspek perilaku individu meliputi sifat tamak atau rakus manusia, moral yang kurang kuat, dan gaya hidup konsumtif. Sementara aspek sosial dapat terjadi karena dorongan perilaku keluarga. Kaum behavioris mengatakan bahwa lingkungan keluarga lah yang secara kuat memberi dorongan bagi orang untuk korupsi dan mengalahkan sifat baik seseorang yang sudah menjadi sifat pribadinya. Lingkungan dalam hal ini malah memberi dorongan dan bukan memberi hukuman pada orang ketika ia menyalahgunakan kekuasaannya.Faktor Eksternal, Aspek sikap masyarakat terhadap korupsi, Nilai-nilai di masyarakat kondusif untuk terjadinya korupsi di antaranya adalah: Masyarakat kurang menyadari bahwa korban utama korupsi adalah masyarakat sendiri, Masyarakat kurang menyadari bila dirinya terlibat korupsi, Masyarakat kurang menyadari bahwa korupsi akan bisa dicegah dan diberantas bila mereka ikut aktif dalam agenda pencegahan dan pemberantasan. Aspek ekonomi, Aspek politis, Aspek organisasi.

6 Alam, Sumarni. "Tinjauan Yuridis Atas Tindak Pidana Korupsi Dalam Praktek di Indonesia" Jurnal Hukum Replik 5. No 2 (2017): 157-171. 


\section{Pertanggungjawaban Pelaku TindakPidana Korupsi Anggaran Pendapatan dan Belanja Kampung Menanga Jaya dalam Perkara Nomor: 13/Pid.Sus-TPK/2020/PN.Tjk}

Pertanggungjawaban pidana pada dasarnya merupakan implementasi tanggungjawab seseorang untuk menerima setiap resiko atau konsekuensi yuridis yang muncul sebagai akibat Tindak Pidana yang dilakukannya. Pertanggungjawaban Pidana ini menuntut adanya kemampuan bertanggungjawab pelaku. Pada Prinsipnya pertanggungjawaban pidana ini sama halnya berbicara mengenai kesalahan (culpabilitas) yang merupakan asas fundamental dalam hukum pidana yang mendalilkan bahwa tiada pidana tanpa kesalahan.

Pertanggungjawaban Pidana didasarkan pada kemampuan bertanggungjawab dimana setiap orang akan diminta peratanggungjawabannya didepan Hukum atas apa yang telah dilakukan dalam hal tidak semua orang dapat menjadi subjek Hukum Pidana, karena yang hanya dapat menjadi subjek Hukum adalah dengan syarat orang tersebut harus cakap dalam melakukan perbuatan Hukum dan mampu mebedakan mana yang baik dan yang tidak baik, termasuk dalam Tindak Pidana Korupsi Anggaran Pendapatan dan Belanja Kampung Menanga Jaya.

Hakim dalam memberikan putusan tidak hanya berdasarkan pada nilai nilai hukum yang hidup dalam masyarakat, hal ini dijelaskan dalam Pasal 28 ayat (1) UU No. 40 Tahun 2009 yaitu: "Hakim wajib menggali, mengikuti, dan memahami nilai-nilai hukum yang hidup dalam masyarakat". Hakim oleh karena itu dalam memberikan putusan harus berdasar penafsiran hukum yang sesuai dengan rasa keadilan yang tumbuh, hidup, dan berkembang dalam masyarakat, juga faktor lain yang mempengaruhi seperti faktor budaya, sosial, ekonomi, politik, dan lain-lain. Dengan demikian seorang hakim dalam memberikan putusan dalam kasus yang sama dapat berbeda karena antara hakim yang satu dengan yang lainnya mempunyai cara pandang serta dasar pertimbangan yang berbeda pula.

Jaksa Penuntut Umum pada Kejaksaan Blambangan Umpu telah melakukan Penuntutan sebagai berikut: 
1. Menyatakan Terdakwa WAHID MAULANA BIN JUIN telah terbukti bersalah secara sah dan meyakinkan melakukan tindak pidana korupsi "Yang melakukan Turut serta melakukan, yang menyuruh melakukan Setiap Orang melakukan perbuatan melawan hukum memperkaya diri sendiri atau orang lain atau suatu korporasi yang dapat merugikan keuangan negara atau perekonomian negara secara berlanjut" sebagaimana diatur dan diancam pidana dalam Pasal 2 ayat (1) Jo. Pasal 18 UndangUndang Nomor 31 Tahun 1999 tentang Pemberantasan Tindak Pidana Korupsi yang dirubah dan ditambah dengan Undang-Undang Nomor 20 tahun 2001 Jo Pasal 55 ke-1 KUHP Jo pasal 64 ayat (1) KUHP sebagaimana dalam dakwaan primair kami;

2. Menjatuhkan pidana oleh karena itu terhadap Terdakwa WAHID MAULANA BIN JUIN dengan pidana penjara selama 6 (enam) Tahun dikurangkan sepenuhnya selama terdakwa ditahan ;

3. Menghukum terdakwa WAHID MAULANA BIN JUIN untuk membayar denda Rp.200.000.000,- (dua ratus juta rupiah) subsidiair 3 (tiga) bulan kurungan;

4. Menjatuhkan pidana tambahan kepada Terdakwa WAHID MAULANA BIN JUIN agar dibebani untuk membayar uang Pengganti sebesar Rp Rp.457.622.500, 00 (empat ratus lima puluh tujuh juta enam ratus dua puluh dua ribu lima ratus rupiah), dengan ketentuan bila Terpidana/Terdakwa tidak membayar uang pengganti tersebut paling lamadalam waktu 1 (satu) bulan sesudah putusan pengadilan memperoleh kekuatan hukum tetap, maka harta bendanya disita oleh Jaksa dan dilelang untuk menutupi uang Pengganti tersebut, dalam hal Terpidana/Terdakwa tidak mempunyai harta benda yang mencukupi untuk membayar uang pengganti tersebut, maka diganti dengan menjalani pidana penjara selama 3 (tiga) tahun penjara;

5. Menyatakan barang bukti berupa: 
1) Satubundel berkas foto copy RPJMK (Rencana Pembangunan Jangka Menengah Kampung ) Kp. Menanga Jaya Kec. Banjit Kab. Way Kanan Tahun 2016.

2) Satu bundel berkas foto copy RKPK ( Rencana Kerja Pemerintahan Kampung ) Kp. Menanga Jaya Kec. Banjit Kab. Way Kanan Tahun 2016

3) Satu bundel berkas foto copy RAPBK ( Rancangan Anggaran Pendapatan dan Belanja Kampung).

4) satubundel SPJ Asli Tahap 1 Kp. Menanga Jaya Kec. Banjit Kab.Way Kanan Tahun 2016.

5) Satu bundel Laporan Transaksi Bank BRI Rekening An. Kp.Menanga Jaya.

6) Satu bundel berkas foto copy legalisir pencairan Alokasi Dana Desa (DD) Tahap ke - I sebesar 60\% Tahun Anggaran 2016 untuk Kp. Menanga Jaya Kec. Banjit sebesar Rp. 365.575.875, - (Tiga ratus enam puluh lima juta lima ratus tujuh puluh lima ribu delapan ratus tujuh puluh lima Rupiah),

7) Satu bundel berkas foto copy legalisir pencairan Alokasi Dana Desa (DD) Tahap ke-II sebesar 40\% Tahun Anggaran 2016 untuk Kp. Menanga Jaya Kec. Banjit sebesar Rp. 243.717.250, - (Dua ratus empat puluh tiga juta tujuh ratus tujuh belas ribu dua ratus lima puluh Rupiah),

8) Satu bundel berkas foto copy legalisir pencairan Alokasi Dana Kampung (ADK) Tahap ke - I sebesar 50\% Tahun Anggaran 2016 untuk kp. Menanga Jaya Kec. Banjit sebesar Rp. 65.358.175, - (Enam puluh lima juta tiga ratus lima puluh delapan ribu seratus tujuh puluh lima rupiah),

9) Satu bundel berkas foto copy legalisir pencairan Alokasi Dana Kampung (ADK) Tahap ke-II sebesar 50\% Tahun Anggaran 2016 untuk kp. Menanga Jaya Kec. Banjit sebesar Rp. 65.358.175, - (Enam 
puluh lima juta tiga ratus lima puluh delapan ribu seratus tujuh puluh lima rupiah),

10) Satu bundel pencairan Berkas pendukung lainnya :

a. Foto copy legalisir Peraturan Bupati Way Kanan Nomor 4 Tahun 2016 tentang Tata Cara Pembagian dan Penetapan Rincian Dana Desa untuk setiap kampung Kabupaten Way Kanan TA.2016.

b. Foto copy legalisir Peraturan Bupati Way Kanan Nomor 7 Tahun 2016 tentang Perubahan atas Peraturan Bupati Way Kanan Nomor 4 Tahun 2016 tentang Tata Cara Pembagian dan Penetapan Rincian Dana Desa untuk setiap kampung Kabupaten Way KananTA.2016.

c. Foto copy legalisir Peraturan Bupati Way Kanan Nomor 13 Tahun2016 tentang tata cara pembagian dan penetapan besaran pembagian Bagi Hasil Kampung di Kabupaten Way Kanan TA.2016.

d. Surat Pernyataan Kepala Kp. Menanga Jaya tanggal 31 Oktober2016.

e. Satu lembar foto Copy legalisir SK Pendamping Lokal Desa.

f. Satu lembar foto copy legalisir SK Kepala Kp. Menanga Jaya.

g. Satu bundel foto copy legalisir SK Perangkat Kp. Menanga Jaya.

h. satu bundel foto copy legalisir dokumen perubahan pelaksanaan anggaran kerja perangkat daerah (DPPA - SKPD), Satuan KerjaPengelolaan Keuangan Daerah (SKPKD) TA 2016.

6. Membebankan kepada terdakwa untuk membayar biaya perkara sebesar Rp.5.000, - (lima ribu rupiah).

Berdasarkan Penelitian di Pengadilan Negeri Tanjung Karang menurut Majelis Hakim Masriati Tindak Pidana Korupsi pada Pengadilan Negeri Tanjung Karang menjatuhkan Pidana terhadap terdakwa dalam Putusan Nomor: 13/Pid.Sus-TPK/2020/PN.Tjk dengan amar Putusan Sebagai berikut: 
1. Menyatakan Terdakwa WAHID MAULANA BIN JUIN telah terbukti secara sah dan meyakinkan bersalah melakukan tindak pidana Korupsi secara bersama-sama dan berlanjut, sebagaimana pada dakwaan primair;

2. Menjatuhkan pidana kepada Terdakwa WAHID MAULANA BIN JUIN oleh karena itu dengan pidana penjara selama 5 (lima) tahun dan denda sebesar Rp 200.000.000, - (dua ratus juta rupiah), dengan ketentuan apabila denda tersebut tidak dibayar oleh terdakwa maka diganti dengan pidana kurungan selama 3 (tiga) bulan;

3. Menghukum terdakwa Terdakwa WAHID MAULANA BIN JUIN untuk membayar uang pengganti kerugian keuangan negara sebesar Rp 457.622.500, 00 (empat ratus lima puluh tujuh juta enam ratus dua puluh dua ribu lima ratus rupiah). Dengan ketentuan apabila Terdakwa tidak membayar uang pengganti dalam waktu 1 (satu) bulan sesudah Putusan Pengadilan memperoleh kekuatan hukum tetap, maka harta bendanya akan disita oleh Jaksa Penuntut Umum dan dapat dilelang untuk menutupi Uang Pengganti tersebut dan dalam hal tidak mempunyai harta benda yang mencukupi untuk membayar Uang Pengganti tersebut, maka dipidana dengan Pidana Penjara selama 2 (dua) tahun ;

4. Menetapkan masa penahanan yang telah dijalani Terdakwa dikurangkan seluruhnya dari pidana yang dijatuhkan;

5. Menetapkan Terdakwa tetap ditahan.

6. Menetapkan barang bukti berupa :

1) Satu bundel berkas foto copy RPJMK ( Rencana Pembangunan Jangka Menengah Kampung ) Kp. Menanga Jaya Kec. Banjit Kab. Way Kanan Tahun 2016.

2) Satu ) bundel berkas foto copy RKPK ( Rencana Kerja Pemerintahan Kampung ) Kp. Menanga Jaya Kec. Banjit Kab. Way Kanan Tahun 2016

3) Satu bundel berkas foto copy RAPBK ( Rancangan Anggaran Pendapatan dan Belanja Kampung). 
4) satu bundel SPJ Asli Tahap $1 \mathrm{Kp}$. Menanga Jaya Kec. Banjit Kab. Way Kanan Tahun 2016.

5) Satu bundel Laporan Transaksi Bank BRI Rekening An. Kp. Menanga Jaya.

6) Satu bundel berkas foto copy legalisir pencairan Alokasi Dana Desa (DD) Tahap ke - I sebesar 60\% Tahun Anggaran 2016 untuk Kp. Menanga Jaya Kec. Banjit sebesar Rp. 365.575.875, - (Tiga ratus enam puluh lima juta lima ratus tujuh puluh lima ribu delapan ratus tujuh puluh lima Rupiah),

7) Satu bundel berkas foto copy legalisir pencairan Alokasi Dana Desa (DD) Tahap ke-II sebesar 40\% Tahun Anggaran 2016 untuk Kp. Menanga Jaya Kec. Banjit sebesar Rp.243.717.250, - (Dua ratus empat puluh tiga juta tujuh ratus tujuh belas ribu dua ratus lima puluh Rupiah),

8) satu bundel berkas foto copy legalisir pencairan Alokasi Dana Kampung (ADK) Tahap ke - I sebesar 50\% Tahun Anggaran 2016 untuk kp. Menanga Jaya Kec. Banjit sebesar Rp. 65.358.175, - (Enam puluh lima juta tiga ratus lima puluh delapan ribu seratus tujuh puluh lima rupiah),

9) satu bundel berkas foto copy legalisir pencairan Alokasi Dana Kampung (ADK) Tahap ke-II sebesar 50\% Tahun Anggaran 2016 untuk kp. Menanga Jaya Kec. Banjit sebesar Rp. 65.358.175, - (Enam puluh lima juta tiga ratus lima puluh delapan ribu seratus tujuh puluh lima rupiah),

10) satu bundel pencairan Berkas pendukung lainnya :

a. Foto copy legalisir Peraturan Bupati Way Kanan Nomor 4 Tahun 2016 tentang Tata Cara Pembagian dan Penetapan Rincian Dana Desa untuk setiap kampung Kabupaten Way Kanan TA.2016.

b. Foto copy legalisir Peraturan Bupati Way Kanan Nomor 7 Tahun 2016 tentang Perubahan atas Peraturan Bupati Way Kanan Nomor 4 Tahun 2016 tentang Tata Cara Pembagian dan Penetapan Rincian 
Dana Desa untuk setiap kampung Kabupaten Way Kanan TA.2016.

c. Foto copy legalisir Peraturan Bupati Way Kanan Nomor 13 Tahun 2016 tentang tata cara pembagian dan penetapan besaran pembagian Bagi Hasil Kampung di Kabupaten Way Kanan TA.2016.

d. Surat Pernyataan Kepala Kp. Menanga Jaya tanggal 31 Oktober 2016.

e. satu lembar foto Copy legalisir SK Pendamping Lokal Desa.

f. Satu lembar foto copy legalisir SK Kepala Kp. Menanga Jaya.

g. satu bundel foto copy legalisir SK Perangkat Kp. Menanga Jaya.

h. Satu bundel foto copy legalisir dokumen perubahan pelaksanaananggaran kerja perangkat daerah (DPPA - SKPD), Satuan KerjaPengelolaan Keuangan Daerah (SKPKD) TA 2016.

7. Membebankan kepada terdakwa membayar biaya perkara sejumlah Rp.10.000, - (sepuluh ribu rupiah);

Undang-Undang Nomor 31 Tahun 1999 tentang Pemberantasan Tindak Pidana Korupsi menerapkan sistem pidana minimal dalam upaya untuk dapat menimbulkan efek jera dan daya tangkal sejalan dengan tujuan undang-undang ini, utnuk mengantisipasi kebutuhan hukum masyarakat dalam mencegah dan memberantas secara efektif segala bentuk tindak pidana korupsi. Dalam Pasal 4 Undang-Undang Nomor 31 Tahun 1999, disebutkan pengembalian kerugian keuangan negara tidak menghapuskan pidana, maksudnya meskipun hasil korupsi telah dikembalikan kepada negara, tidak menghapus sifat melawan hukum, perbuatan dan pelaku akan tetap diajukan ke pengadilan dan dijatuhi pidana, hanya hukumannya diperingan.

Unsur melawan hukum merupakan perbuatan yang bertentangan dengan peraturan perundang-undangan yang bisa dilakukan oleh setiap orang.Sedangkan menyalahgunakan wewenang adalah juga perbuatan yang bertentangan dengan peraturan perundang-undangan, hanya bisa dilakukan oleh seseorang yang 
mempunyai kewenangan dan kapasitas tertentu yang terkait dengan jabatannya terkait dengan prosedural. Menyalahgunakan kewenangan, kesempatan, atau sarana yang ada terkait dengan posisinya selaku penyelenggara negara atau pegawai negeri Institusi itu secara salah, dapat disebut sebagai menyalahgunakan kewenangan, kesempatan, atau sarana yang ada padanya karena jabatan atau kedudukan dan kewenangan tersebut digunakan tidak sesuai dengan tugas jabatannya. Selanjutnya unsur memperkaya diri atau orang lain atau suatu korporasi dan unsur dengan tujuan menguntungkan diri sendiri atau orang lain atau suatu korporasi merupakan unsur yang besifat alternatif sehingga tidak perlu pelaku tindak pidana korupsi harus menikmati sendiri uang hasil tindak pidana korupsi.

Terdakwa tersebut melakukan Tindak Pidana Korupsi secara bersama-sama dalam Anggaran Pendapatan dan Belanja Kampung Menanga Jaya.Unsur merugikan keuangan Negara maksudnya adalah anggaran yang telah ditetapkan tidak dipergunakan sesuai dengan peruntukannya atau terjadi penyimpangan.

\section{Upaya Pengembalian Kerugian Negara Akibat Tindak Pidana} Korupsi Anggaran Pendapatan dan Belanja Kampung Menanga Jaya Dalam Perkara Nomor:13/Pid.Sus-TPK/2020/PN.Tjk

Ada empat tahapan dalam teori pengembalian aset negara, yaitu:

1. Teori Penelurusan Aset, tahap pertama dari pengembalian aset tindak pidana korupsi adalah tahap pelacakan aset. Untuk menjaga lingkup dan arah tujuan investigasi menjadi fokus, menurut John Conyngham, otoritas yang melakukan investigasi atau melacak aset-aset tersebut bermitra dengan firma-firma hukum dan firma akuntansi. Untuk kepentingan investigasi dirumuskan praduga bahwa pelaku tindak pidana akan mengagunkan dana-dana yang diperoleh secara tidak sah untuk kepentingan pribadi dan keluarganya.

2. Teori pembukuan aset,

Tahap kedua adalah tahap pembekuan. Menurut UNCAC 2003, pembekuan atau pengembalian berarti larangan sementara TEORI untuk 
mentransfer, mengkonversi, mendisposisi, atau memindahkan kekayaan atau untuk sementara dianggap sebagai ditaruh di bawah perwalian atau dibawah pengawasan berdasarkan perintah pengadilan atau badan yang berwenang lainnya.

3. Teori penyitaan aset

Tahap ketiga penyitaan aset-aset. Biasanya perintah penyitaan dikeluarkan oleh pengadilan atau badan yang berwenang dari negara penerima setelah ada putusan pengadilan yang menjatuhkan pidana kepada pelaku tindak pidana.

4. Pengembalian Aset adalah kerugian Negara korban Tindak Pidana Korupsi yang ditimbulkan oleh pelaku Tindak Pidana Korupsi

Pengembalian kerugiaan Negara melalui uang pengganti merupakan hal yang sangat penting, karena uang tersebut dapat dipergunakan untuk melanjutkan pembangunan. Pengembalian tersebut tidaklah mudah karena proses peradilan tindak pidana korupsi pada umumnya membutuhkan waktu yang lama, sehingga terpidana mempunyai kesempatan untuk mengalihkan atau menyembunyikan harta bendanya yang berasal dari tindak pidana korupsi. Selain itu tindak pidana korupsi merupakan extra ordinary crimes, dimana pelakunya adalah kalangan intelektual dan mempunyai kedududkan penting, sehingga mudah untuk mengalihkan/menyembunyikan harta bendanya yang berasal dari hasil korupsi. Sehubungan dengan Pasal 18 ayat (2) Undang-Undang Nomor 31 Tahun 1999 tentang pemberantasan Tindak Pidana Korupsi sebagaiamana telah diubah dengan Undang-Undang Nomor 20 Tahun 2001 menyatakan bahwa jika terpidana tidak membayar uang pengganti sebagaimana dimaksud ayat (1) huruf b paling lama waktu 1 bulan sesudah putusan pengadilan yang memperoleh kekuatan Hukum tetap, maka harta bendanya dapat disita oleh jaksa dan dilelang untuk menutupi uang pengganti tersebut.

Upaya untuk melunasi uang pengganti, jaksa dapat menyita dan melelang harta benda terpidna setelah Putusan Pengadilan mempunyai kekuatan Hukum tetap. Apabila ketentuan ini dilaksanakan, jaksa akan menemui kesulitan dalam 
menentukan harta benda milik terpidana atau ahli warisnya. Dan kemungkinan timbulnya tunggakan uang pengganti sangat besar, oleh karena pendataan dan penyitaan harta benda milik terpidana harusnya sudah dilakukan sejak penyidikan. Untuk itu memerlukan optimalisasikan tugas dan fungsi kejaksaan di bidang intelejen dalam menemukam harta kekayaan Negara yang korupsi tidak terhenti pada proses penyidikan tetapi terus berlanjut pada penuntutan, eksekusi dan upaya perdata.

Selain itu upaya lain yang dapat ditempuh adalah pelunasan uang pengganti dengan hukuman badan. Penyelesaian tunggakan uang pengganti disamping dilakukan dengan penyitaan dan pelelangan harta benda terpidana juga dapat dilakukan melalui tuntutan subsider pidana penjara atau hukuman badan. Tuntutn Pidana penjara diatur dalam Pasal 18 ayat (3) Undang-Undang Nomor 31 Tahun 1999 tentang Pemberantasan Tindak Pidana Korupsi sebagaimana telah diubah dengan Undang-Undang Nomor 20 Tahun 2001, menegaskan bahwa dalam hal terpidana tidak mempunyai harta benda yang mencukupi untuk membayar uang pengganti sebagaimana dimaksud dalam ayat (10 huruf b maka dipidana dengan pidana penjara yang lamanya tidak melebihi ancaman maksimal dari pidana pokoknya sesuai dengan ketentuan dalam Undang-Undang. Dan lamanya pidana tersebut sudah ditentukan dalam Putusan Pengadilan.

Berkenaan dengan itu berdasarkan Rekomendasi Rapat Kerja Kejaksaan Se Indonesia Tahun 2005 bahwa jaksa harus selalu mencatumkan tuntutan subsider pidana penjara apabila terpidana dalam waktu 1 bulan tidak melunasi uang pengganti. Dalam penyelesaian tunggakan uang pengganti melalui hukuman subside permasalahan yang dihadapi dalam praktek adalah terpidana akan memilih melaksanakan hukuman subsider daripada membayar uang pengganti jika hukuman subsidernya lebih menguntungkan daripada pembayaran uang penggantinya. Oleh karena itu jaksa dalam menuntut hukuman subside hendaknya menuntut hukuman maksimal sesuai ketentuan Pasal yang dilanggar. 
Kejaksaan juga dapat menempuh penyelesaian tunggakan uang pengganti melalui upaya perdata dan administrasi keuangan. Penyelesaian tunggakan uang pengganti melalui uapaya perdata dilakukan apabila setelah Putusan Pengadilan memperoleh kekuatan hukum tetap diketahui masih terdapat harta benda milik terpidana diduga berasal dari Tindak Pidana Korupsi beum dirampas (Pasal $38 \mathrm{~b}$ Undang-Undan Nomor 31 Tahun 1999). Sebagaimana telah dikemukakan sebelumnya bahwa Tindak Pidana Korupsi merupakan extra ordinary crimes yang dilakukan oleh kalangan intelektual sehingga hilangnya alat-alat buti, khususnya alat-alat bukti yang berguna dalam proses pembuktian gugatan perdata sangat besar. Hilangnya alat bukti tersebut akan berakibat sulitnya bagi jaksa pengacara Negara untuk menang dalam perkara perdata yang ditanganinya. Sedangkan penyelesaian tunggakan uang pengganti melalui administrasi keuangan Negara dilakukan karena terjadinya perbedaan perbedaan jumlah uang pengganti menurut versi kejaksaan dengan Departemen Keuangan. Hal ini antara lain disebabkan sistem pembukuan uang pengganti di Kejaksaan belum menganut sistem akuntansi instansi yang disusun oleh Kementerian Keuangan.

Berdasarkan hasil wawancara penulis dengan Achmad Rendra Pratama R, selaku jaksa maka diketahui bahwa tujuan pokok diterapkan pidana tambahan pembayaran uang pengganti adalah untuk mengembalikan kerugiaan uang Negara yang dikorupsi oleh pelaku, sehingga dengan demikian keuangan Negara diharapkan dapat dipulihkan, diselamatkan, dikembalikan nilainya seperti dalam keadaan semula.

Berdasarkan wawancara kepada Sumitro selaku kepala BPKP perwakilan Provinsi Lampung diketahui bahwa peraturan Perundang-Undangan mengakui istilah keuangan Negara dan pengembalian asset merupakan nomenklatur baru dan tersendiri, terpisah dari istilah keuangan Negara. Istilah ini jelas menunjukkan secara eksplisit bahwa asset hasil korupsi adalah serta merta merupakan harta kekayaan Negara. Sedangkan harta kekayaan pihak ketiga yang beritikad baik dan juga mereka yang dirugikan karena suap/korupsi tidak memperoleh perlindungan Hukum. 
Upaya pengendalian kerugiaan Negara akibat Tindak Pidana Korupsi dana Anggaran Pendapatan dan Belanja Kampung Menanga Jaya dalam Perkara Nomor: 13/Pid.Sus-Tpk/2020/Tjk. Dilaksanakan dengan pelelangan aset, penyitaan aset, pembekuan aset, dan pelelangan aset milik terpidana dan ahli warisnya setelah Putusan Pengadilan mempunyai kekuatan Hukum tetap, melalui Putusan subside Pidana penjara, melalui gugatan Perdata dan administrasi keuangan.

\section{Penutup}

Faktor penyebab Tindak Pidana Korupsi dana Anggaran Pendapatan dan Belanja Kampung Menanga Jaya Dalam Perkara Nomor: 13/Pid.SusTpk/2020/Tjk adalah Kurang adanya sikap keteladanan pimpinan, Tidak adanya kultur organisasi yang benar, Kurang memadainya sistem akuntabilitas yang benar, Kelemahan sistem pengendalian manajeme, Lemahnya pengawasan. Menyalahgunakan dibidang anggran dengan cara melakukan Korupsi Anggaran yang mengakibatkan kerugian keuangan Negara dan minimnya partisipasi masyarakat dalam pengawasan sehingga mempermudah terdakwa melakukan Tindak Pidana Korupsi.

Pertanggungjawaban Pidana pelaku Tindak Pidana Korupsi dana Anggaran Pendapatandan Belanja Kampung Menanga Jaya Dalam Perkara Nomor: 13/Pid.Sus-Tpk/2020/Tjk. Dilakukan dengan pemidanaan terhadap terdakwa yaitu Wahid Maulana Bin Juin dengan Pidana Penjara selama 5 (lima) tahun dan denda sebesar Rp 200.000.000, - (dua ratus juta rupiah) dengan ketentuan apabila denda tersebut tidak dibayar oleh terdakwa maka diganti dengan pidana kurungan selama 3 (tiga) bulan. Selain itu terdakwa juga dipidana untuk membayar uang pengganti kerugian keuangan negara sebesar Rp 457.622.500, 00 (empat ratus lima puluh tujuh juta enam ratus dua puluh dua ribu lima ratus rupiah). Sebagai bentuk pertanggungjawaban dan arena memenuhi unsur kesalahan dan kesengajaan dalam melakukan Tindak Pidana.

Upaya pengendalian kerugiaan Negara akibat Tindak Pidana Korupsi dana Anggaran Pendapatan dan Belanja Kampung Menanga Jaya Dalam Perkara 
Nomor: 13/Pid.Sus-Tpk/2020/Tjk. Dilaksanakan dengan pelelangan aset, penyitaan aset, pembekuan aset, dan pelelangan aset milik terpidana dan ahli warisnya setelah Putusan Pengadilan mempunyai kekuatan Hukum tetap, melalui Putusan subsider Pidana penjara, melalui gugatan Perdata dan administrasi keuangan.

\section{Daftar Pustaka}

Alam, Sumarni. Tinjauan Yuridis Atas Tindak Pidana Korupsi Dalam Praktek di Indonesia. Jurnal Hukum Replik 5. No 2 (2017): 157-171.

BPKP, Strategi Pemberantasan Korupsi Nasional, (Jakarta: Pusat Pendidikan dan Pengawasan BPKP, Cet I, 1999) hlm 257-258

dChaerudin, Syaiful Ahmad Dinar, Syarif Fadillah. Strategi Pencegahan dan Penegakan Hukum Tindak Pidana Korupsi. ( Bandung : PT Refika Aditama, 2008). hlm. 2.

Eddy Mulyadi Soepardi. Memahami kerugian negara sebagai salah satu unsur tindak pidana. (Yogyakarta: Ghalia, 2009) hlm. 3.

Hamzah Andi. Pemberantasan Korupsi melalui Hukum Pidana Nasional dan Internasional, (Jakarta, Raja Grafindo Persada, 2005) Hlm. 13-23 